\title{
Faktor Internal Dan Ekternal yang Mempengaruhi Permintaan Sukuk Negara Ritel
}

\author{
Gusniarti \\ Universitas Muhammadiyah Prof. DR. HAMKA \\ Email: gusniarti30@gmail.com \\ Dini Primasuci \\ BNI Syariah \\ Email:diniprimasuci@yahoo.com
}

\begin{abstract}
This study aims to analyze what factors can influence the demand for retail state sukuk. This study uses multiple regression analysis. The research data used is the SR004-007 Retail Sukuk as the dependent variable. The independent variable used is the variable rate of return, price, exchange rate (US dollar exchange rate), inflation, and deposit rates. The results obtained indicate that the variable US dollar exchange rate and deposit rates have an influence on demand for sukuk and yields, prices, and inflation have no effect on demand for retail state sukuk. Based on these results, it shows that retail sukuk yields, retail sukuk prices and inflation in the study period did not affect investors in making decisions to invest in retail state sukuk. While the increase in the US dollar exchange rate caused by the economic slowdown in the study period and deposit interest rates that compete closely with the returns on retail sukuk can influence investors in making decisions to invest in retail state sukuk.
\end{abstract}

Keywords: Retail State Sukuk, US Dollar Exchange Rate, Inflation, Deposit Interest Rate.

\begin{abstract}
Abstrak : Penelitian ini bertujuan untuk menganalisis faktor apa saja yang dapat mempengaruhi permintaan sukuk negara ritel. Penelitian ini menggunakan analisis regresi berganda. Data penelitian yang digunakan adalah Sukuk Ritel SR004-007 sebagai variabel dependen. Variabel independen yang digunakan ialah variable tingkat imbal hasil, harga, nilai tukar (kurs dolar AS), inflasi, dan suku bunga deposito. Hasil yang didapat menunjukkan bahwa variabel kurs dolar AS dan suku bunga deposito memiliki pengaruh terhadap permintaan sukuk dan imbal hasil, harga, serta inflasi tidak berpengaruh terhadap permintaan sukuk negara ritel. Berdasarkan hasil ini, menunjukan bahwa imbal hasil sukuk ritel, harga sukuk ritel dan inflasi pada periode penelitian tidak mempengaruhi investor dalam pengambilan keputusan untuk berinvestasi sukuk negara ritel. Sedangkan kenaikan kurs dolar AS yang di sebabkan terjadinya perlambatan ekonomi pada periode penelitian dan tingkat suku bunga deposito yang bersaing ketat dengan tingkat imbal hasil sukuk ritel dapat mempengaruhi investor dalam pengambilan keputusan untuk berinvestasi sukuk negara ritel.
\end{abstract}

Kata kunci : Sukuk Negara Ritel, Kurs Dolar AS, Inflasi, Suku Bunga Deposito. 


\section{PENDAHULUAN}

Seiring dengan perkembangan zaman, perdagangan yang berlangsung tidak hanya menjual belikan aset-aset riil tetapi juga asetaset keuangan (financial assets) seperti surat berharga (sekuritas). Tempat untuk memperdagangkan aset-aset itu disebut bursa efek. Instrumen sekuritas yang umum diperdagangkan di bursa efek salah satunya adalah obligasi.

Menurut Sawidji Obligasi termasuk dalam kelompok investasi yang merupakan investasi harta tetap (fix asset investment). Dikatakan investasi harta tetap, karena untuk dapat melakukan investasi pada obligasi, investor harus memiliki uang tertentu untuk dikaitkan pada obligasi dalam jangka waktu tertentu obligasi menjadi sangat menarik. Ini terbukti dengan semakin banyaknya perusahaan yang melakukan emisi obligasi. Apalagi dewasa ini pemerintah pusat banyak menerbitkan obligasi pemerintah untuk menutup defisit APBN, terutama obligasi untuk investor ritel yang dikenal sebagai ORI (Obligasi Negara Ritel).

Seiring dengan semakin diakuinya konsep keuangan berbasis syariah maka diperlukan pula perdagangan efek yang sesuai dengan prinsip syariah. Transaksi jual beli yang dilakukan suka sama suka, harga yang disepakati, dan alat tukar yaitu uang. Karena itu, transaksi sekuritas telah memenuhi rukun dan syarat jual beli menurut fikih. Transaksi yang dilakukan melalui pialang sekuritas pun tidak dianggap melanggar kaidah fikih. Islam memperbolehkan transaksi jual beli yang diwakilkan kepada perantara.

$$
\text { Burhanuddin }{ }^{1} \text { mengatakan bahwa }
$$

konsep keuangan berbasis syariah Islam (Islamic Finance) sekarang ini, telah mengalami pertumbuhan secara pesat, diterima secara universal dan diadopsi tidak hanya oleh negara-negara Islam melainkan oleh berbagai negara lain di belahan dunia. Fenomena ini ditandai dengan didirikannya lembaga-lembaga keuangan, untuk menerbitkan berbagai instrumen pembiayaan berbasis syariah. Disamping itu, pada tingkat global juga dibentuk lembaga internasional untuk merumuskan infrastruktur sistem ekonomi Islam, lengkap dengan standar instrumen keuangan syariah yang telah banyak diterbitkan baik oleh korporasi maupun negara adalah instrumen sukuk. Istilah sukuk merupakan nama lain dari obligasi syariah yang menjadikan akad-akad muamalah sebagai dasar transaksi (underlying transaction).

Melihat pesatnya perkembangan sukuk di negara-negara lain, serta pengalaman yang terjadi selama ini, terutama

1 Burhanuddin S., Hukum Surat Berharga Syariah Negara dan Pengaturannya. (Jakarta : Rajawali Pers 2011), h. 10 
dari segi manfaat yang ditimbulkannya, pemerintah merasa berkepentingan mengeluarkan regulasi yang dapat mendukung perkembangan sukuk di dalam negeri. Sebagai tindak lanjut, penerapan sukuk diwujudkan ke dalam bentuk penerbitan Surat Berharga Syariah Negara (SBSN). Tujuan penerbitan SBSN adalah dalam rangka mencari alternatif sumber pembiayaan negara, di mana ketentuannya diatur dalam Undang-undang SBSN No. 19 Tahun 2008. ${ }^{2}$ SBSN Ritel yang saat ini dikenal dengan Sukuk Negara Ritel merupakan salah satu investasi yang banyak diminati emiten karena menggunakan prinsip syariah dengan sistem imbal hasil.

Lalu, bagaimana dengan keterbukaan dan transparansi kondisi emiten apakah memenuhi kaidah fikih? Prinsip keterbukaan dan transparansi informasi penuh (Full disclosure) diperlukan agar investor tidak dirugikan dan terhindar dari penyelewengan dan penipuan. Emiten yang tidak full disclosure dapat merugikan perusahaan itu sendiri karena perusahaan tersebut harus menanggung kerugian yang diderita investor dan dapat dikenai sanksi oleh otoritas pasar

2 Burhanuddin S., Hukum Surat Berharga Syariah Negara dan Pengaturannya. (Jakarta : Rajawali Pers 2011), h. 12 modal $^{3}$. Jelas hal ini memenuhi kaidah fikih, karena transaksi yang di ajarkan dalam Islam adalah transaksi yang dilakukan dengan prinsip syariah yaitu sama sama suka atau saling ridha antara pihak satu dengan yang lainnya dalam bertransaksi. Oleh karena itu, sangat diperlukannya investasi dengan prinsip syariah yang menggunakan sistem bagi hasil.

Nur Rianto ${ }^{4}$ mengatakan bahwa salah satu faktor yang mempengaruhi masyarakat untuk berinvestasi adalah nilai tukar mata uang rupiah. Sebagai nilai untuk merepresentasikan tingkat harga pertukaran dari satu mata uang lainnya dan digunakan dalam berbagai transaksi, antara lain transaksi perdagangan internasional, turisme, investasi internasional, ataupun aliran uang jangka pendek antar negara yang melewati batas-batas geografis ataupun batas-batas hukum. Transaksi-transaksi tersebut yang memungkinkan akan mempengaruhi naik turunnya nilai tukar rupiah terhadap mata uang negara lain.

Menurut Sadono 5 tingkat harga, suku bunga dan investasi merupakan salah satu faktor yang menyebabkan menurunya

3 HR, Muhamad Nafik. Bursa Efek dan Investasi Syariah. (Jakarta: PT Serambi Ilmu Semesta 2009). h. 59

${ }^{4}$ Al Arif, M.Nur Rianto. Teori Makroekonomi Islam; Konsep, Teori, dan Analisis. (Bandung: Alfabeta, 2010). h. 70

5 Sukirno, Sadono. Makro Ekonomi; Teori Pengatar. (Jakarta: Rajawali Pers, 2013). h. 55 
permintaan agregat. Pada umumnya terdapat keterkaitan yang cukup rapat di antara perubahan tingkat harga dengan suku bunga. Apabila harga adalah stabil, atau tingkat inflasi sangat rendah, suku bunga cenderung akan menjadi semakin tinggi. Oleh karena itu, jika tingkat inflasi sangat tinggi maka akan menaikkan harga.

Ketika harga mengalami penurunan, permintaan barang dan jasa akan meningkat. Ada tiga alasan untuk hubungan yang negatif ini, yaitu (1) konsumen menjadi lebih kaya sehingga meningkatkan permintaan barangbarang konsumsi, (2) tingkat suku bunga yang turun yang mendorong permintaan terhadapa barang-barang investasi, dan (3) nilai tukar mata uang terdepresiasi yang mendorong permintaan untuk ekspor neto. ${ }^{6}$ Begitu juga sebaliknya jika terjadinya kenaikan harga maka permintaan barang dan jasa maupun investasi akan menurun.

Martin $^{7}$ mengatakan bahwa tingkat suku bunga menentukan nilai tambah mata uang suatu negara. Semakin tinggi suku bunga suatu mata uang, akan semakin tinggi pula permintaan akan mata uang negara tersebut. Tingkat suku bunga diatur oleh

6 Mankiw, N. Gregory. Dkk. Pengantar Ekonomi Makro. (Jakarta: Salemba Empat, 2013). h. 122

7 Martin. "Pengaruh Suku Bunga Terhadap Nilai Tukar Mata Uang." http://seputarforex.com/artikel/forex/lihat.php?id=128 564\&title=pengaruh_suku_bunga_terhadap_nilai_tuk ar_mata_uang (diakses 21 April 2016) bank sentral, dan jika dalam jangka panjang bank sentral selalu menaikkan suku bunga maka trend nilai tukar mata uang negara tersebut terhadap negara lain akan cenderung naik. Sejalan dengan yang dikatakan oleh Rozik dan Mufti bahwa bunga diberikan untuk mengimbangi laju inflasi yang mengakibatkan menyusutnya nilai uang rupiah. Sejumlah uang pada masa kini mempunyai nilai yang lebih tinggi dari jumlah yang sama pada suatu masa nanti, oleh karena itu bunga diberikan untuk mengimbangi penurunan nilai uang ini. Berapa tepatnya besaran nilai tukar rupiah terhadap dolar akan tergantung pada suku bunga.

Kenaikan suku bunga acuan AS the Fed yang tertunda menjadi salah satu faktor dari gejolak ekonomi global. Terkait sukuk, obligasi syariah Indonesia dinilai masih akan laku mengingat perkiraan ekonomi nasional tahun ini masih lebih baik. Ekonom Bank Mandiri Andry Asmoro menuturkan, sama seperti obligasi, sukuk global Indonesia juga turut terpengaruh ekonomi global, yakni kenaikan suku bunga Federal Reserve, penurunan harga minyak, dan pelemahan ekonomi Cina. Pengaruhnya terutama pada permintaan dan imbal hasil. Ia me mengatakan, kenaikan Fed Fund Rate akan membuat investor meminta imbal hasil lebih 
tinggi ${ }^{8}$. Pernyataan tersebut dapat meyakinkan penulis bahwa tingkat permintaan investor obligasi konvensional terpengaruh atas kenaikan suku bunga, sehingga investor beralih pada sukuk yang yang menggunakan sistem imbal hasil.

Berdasarkan pernyataan-pernyataan diatas memungkinkan bahwa nilai tukar berpengaruh terhadap permintaan investor obligasi konvensional. Karena keterkaitannya yang sangat erat antara nilai tukar dengan suku bunga dan juga inflasi. Sedangkan sukuk yang merupakan obligasi syariah dengan menggunakan sistem imbal hasil, apakah terpengaruh dengan kenaikan nilai tukar.

Pada tahun 2015, pemerintah kembali menerbitkan Sukuk Negara Ritel seri baru, yaitu seri SR-007. Berikut adalah grafik penerbitan sukuk negara ritel dari tahun 2009 sampai dengan tahun 2015.
${ }^{8}$ Pratiwi, Fuji. "Inflasi Stabil Pengaruhi Suku Bunga”, Republika (Ekonomi), (Jakarta, 23 Maret, 2016), h. 2

\section{Gambar 1 \\ Grafik Penerbitan Sukuk Negara Ritel}

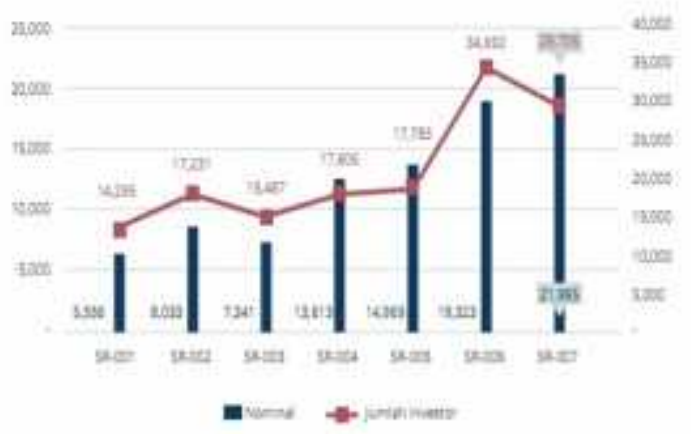

Sumber: Laporan Kinerja Kementrian Keuangan 2015

Berdasarkan gambar 1 diatas menunjukkan penjualan sukuk ritel SR 001 tahun 2009 sampai dengan SR 006 tahun 2014 memiliki hubungan positif antara volume penerbitan dan jumlah investor, ketika volume penerbitan meningkat maka jumlah investor yang melakukan permintaan sukuk ritel meningkat, begitu juga sebaliknya. Tetapi permintaan pada sukuk ritel SR 007 tahun 2015 mengalami penurunan sejumlah $\mathrm{Rp} 29,706$ triliun dari permintaan pada sukuk ritel SR 006 yang berjumlah Rp 34,697 triliun. Sedangkan volume penerbitan SR 006 dan SR 007 mengalami peningkatan dari $\mathrm{Rp}$ 19,323 triliun menjadi Rp 21,965 triliun.

Pemerintah telah menerbitkan sukuk ritel SR 001, SR 002, SR 003, SR 004, SR 005, SR 006, dan SR 007. Untuk SR 001 memberikan imbal hasil 12\%, SR 002 dengan imbal hasil sebesar 8,7\%, SR 003 
dengan imbal hasil sebesar 8,15\%, SR 004 dengan imbal hasil sebesar 6,5\%, SR 005 dengan imbal hasil sebesar 6\%, SR 006 dengan imbal hasil sebesar $8,75 \%$ (Ramdhania 2013), dan yang terakhir SR 007 dengan imbal hasil 8,25\%.

Hal ini membuktikan daya beli masyarakat terhadap sukuk ritel mengalami penurunan pada SR 007 tahun 2015, meskipun imbal hasil yang diberikan sebesar $8,25 \%$ lebih besar dibandingkan dengan suku bunga bank yang hanya sebesar 7,5\% . Sedangkan seharusnya daya beli masyarakat meningkat, karena volume penerbitan yang ditawarkan pemerintah lebih banyak dari tahun tahun sebelumnya dan imbal hasil yang ditawarkan lebih besar dibandingkan suku bunga konvensional saat itu.

Desi dan Rohmawati ${ }^{9}$ menyatakan bahwa nilai tukar valas akan menentukan imbal hasil investasi riil. Mata uang yang menurun secara jelas akan mengurangi daya beli dari pendapatan dan keuntungan modal yang didapat dari jenis investasi apapun.

\section{Gambar 2 \\ Fluktuasi Nilai Tukar (Maret 2014- Januari 2015)}

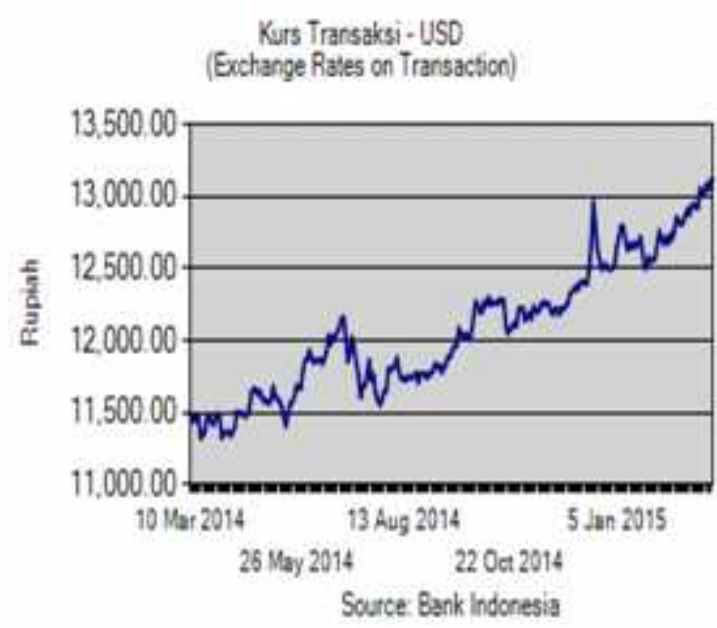

Sumber: Informasi Kurs Bank Indonesia

Gambar 3

Fluktuasi Nilai Tukar (Januari 2015Oktober 2015)

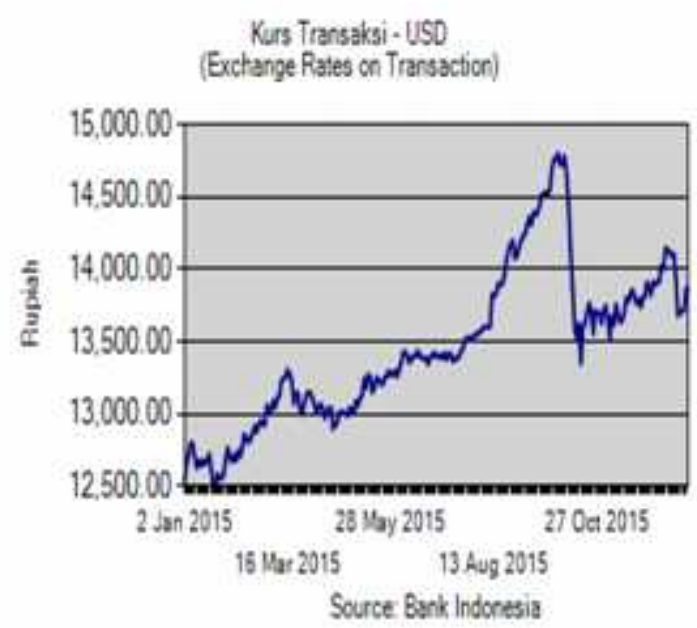

Sumber: Informasi Kurs Bank Indonesia

Berdasarkan gambar grafik di atas, memperjelas bahwa kenaikan nilai tukar rupiah terhadap USD sangat tinggi. Tahun 2014 masih berkisar Rp 11.000,- sampai Rp 12.000,-, di tahun 2015 melonjak naik hingga Rp 14.000,- sampai hampir
9 Swandayani, Desi Marlin \& Rohmawati Kusumaningtias, " Pengaruh Inflasi, Suku Bunga, Nilai Tukar Valas dan Jumlah Uang Beredar terhadap Profitabilitas pada Perbankan Syariah di Indonesia Periode 2005-2009," Akrual 3, 2012. h. 25 
menyentuh angka Rp 15.000,-. Kenaikan nilai tukar di tahun 2015 yang bersamaan dengan terjadinya penurunan permintaan investor pada sukuk ritel SR 007, membuat penulis ingin menganalisa secara lebih dalam terhadap faktor-faktor apa saja yang mempengaruhi permintaan sukuk negara ritel.

Fuji ${ }^{10}$ mengatakan bahwa kenaikan nilai tukar rupiah terhadap USD yang bergantung kepada kenaikan suku bunga konvensional tidak mempengaruhi daya beli atau permintaan investor pada sukuk ritel 007. Karena berdasarkan teori yang ada, produk bursa efek yang menggunakan intrumen bunga (riba) seperti obligasi, jelas dilarang dalam Islam. Pada transaksi yang menggunakan instrumen bunga, return yang diberikan bersifat tetap, tanpa memandang kondisi keuangan perusahaan tersebut apakah ia rugi atau untung. Instrumen demikian tentunya dapat menyebabkan salah satu pihak dirugikan dan ini tampak jelas pada instrumen obligasi, karena obligasi yang ada pada pasar modal konvensional adalah berbasis bunga ${ }^{11}$. Intrumen bagi hasil atau sewa merupakan alternatif yang dapat digunakan untuk menggantikan sistem

10 Pratiwi, Fuji, "Penerbitan Sukuk Dolar Dinilai Positif," Republika (Syariah), Jakarta, 19 Desember, 2015. h. 54

11 Jusmaliani. Dkk. Bisnis Berbasis Syariah. Jakarta: Bumi Aksara,2008. h. 45 bunga. Dengan tidak digunakannya intrumen bunga maka tidak ada kendala bagi seorang muslim untuk melakukan aktivitas di bursa efek, terutama ketika memilih produk obligasi, seperti halnya sukuk.

Berdasarkan latar belakang ini maka penulis tertarik untuk menulis permasalahan dengan mengambil judul: "Faktor Internal dan Eksternal Yang Mempengaruhi Permintaan Sukuk Negara Ritel Periode 2012-2016.”

\section{METODE}

\section{Data Penelitian}

Ruang lingkup dalam penelitian ini adalah menganalisis pengaruh Tingkat Imbal Hasil Sukuk Ritel, Harga Sukuk Ritel, Nilai Tukar (Kurs Dolar AS), Inflasi dan Suku Bunga, terhadap Permintaan Sukuk Negara Ritel. Penelitian ini bersifat kuantitatif atas data sekunder time series menggunakan analisis regresi linier berganda dengan purposive sampling yaitu metode pemilihan sampel dengan kriteria tertentu dalam melakukan pemilihan sampel. Dalam hal ini pertimbangan yang diambil adalah data bulanan sukuk ritel SR 004 pada tahun 2012, SR 005 pada tahun 2013, SR 006 pada tahun 2014, dan SR 007 pada tahun 2015-2016.

\section{Pengumpulan Data}

Metode pengumpulan data dalam penelitian ini adalah metode kuantitatif 
dengan tehnik mengumpulan data dokumentasi. Teknik dokumentasi merupakan teknik pengumpulan data yang secara tidak langsung tidak ditunjukkan kepada subjek penelitian, melainkan kepada dokumen-dokumen tertentu. Dalam penelitian ini, jenis data yang digunakan adalah data sekunder. Data sekunder adalah data yang diperoleh dari literatur kepustakaan, buku-buku, dan lain-lain. Sumber data yang digunakan dalam penelitian yaitu dokumen perdagangan sukuk negara ritel SR 004 - SR 007 periode tahun 2012 - 2016. Data didapatkan dari website Bank Indonesia, Bursa Efek Indonesia (BEI), Kementrian Keuangan serta diperoleh dari berbagai dokumen, literatur, dan referensi lain dari membaca buku-buku, majalah, karya ilmiah, makalah, dan lain-lain yang mengandung informasi berkaitan dengan masalah yang dibahas, yang terhimpun dari berbagai tempat mulai dari perpustakaan hingga situs internet. Teknik menentukan sampel yaitu dengan purposive sampling. Purposive sampling adalah penarikan sampel secara purposif, yaitu cara penarikan sampel yang dilakukan dengan memilih subjek berdasarkan kriteria spesifik yang ditetapkan peneliti.

\section{Metode Analisis Data}

\section{Uji Asumsi Klasik \\ a) Uji Normalitas}

Uji normalitas bertujuan untuk menguji apakah dalam model regresi, variabel pengganggu atau residual memiliki distribusi normal. ${ }^{12}$

1) Analisis Statistik

Tabel 1

Hasil Uji Normalitas dengan Kolmogorov

One-Sample Kolmogorov-Smirnov Test

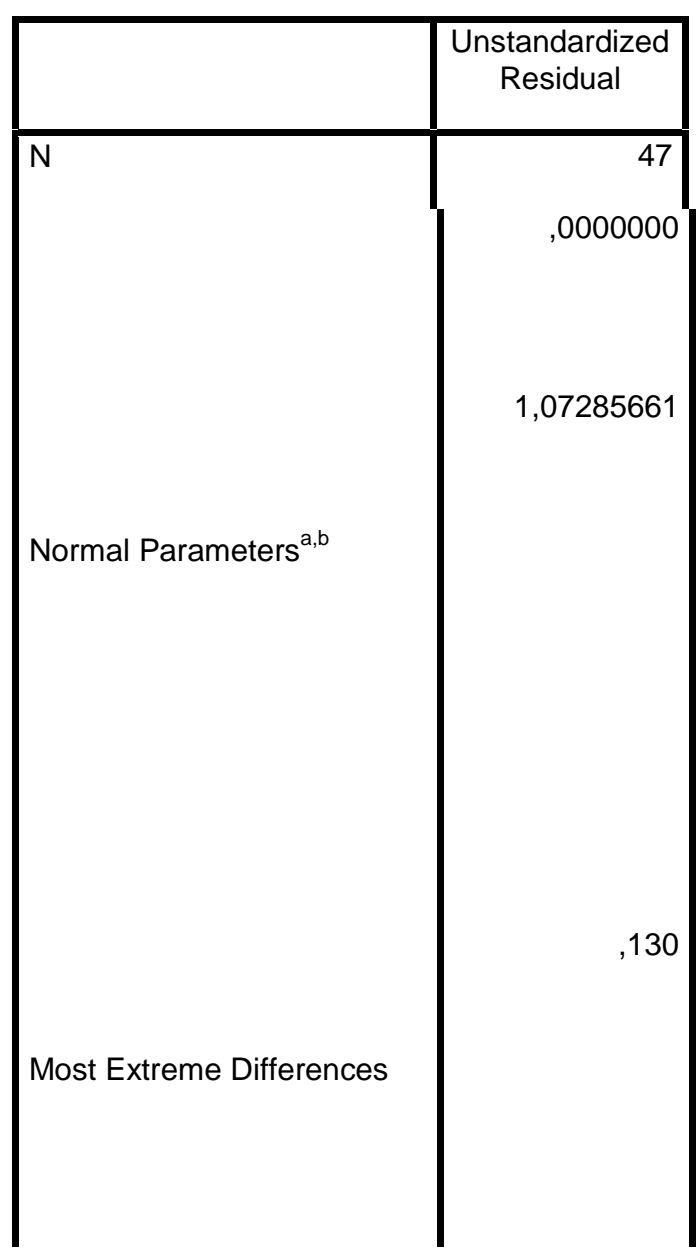

12 Ghozali, Imam. Aplikasi Analisis Multivariate dengan SPSS. (Semarang: Badan Penerbit Universitas Diponegoro, 2005). h. 80 


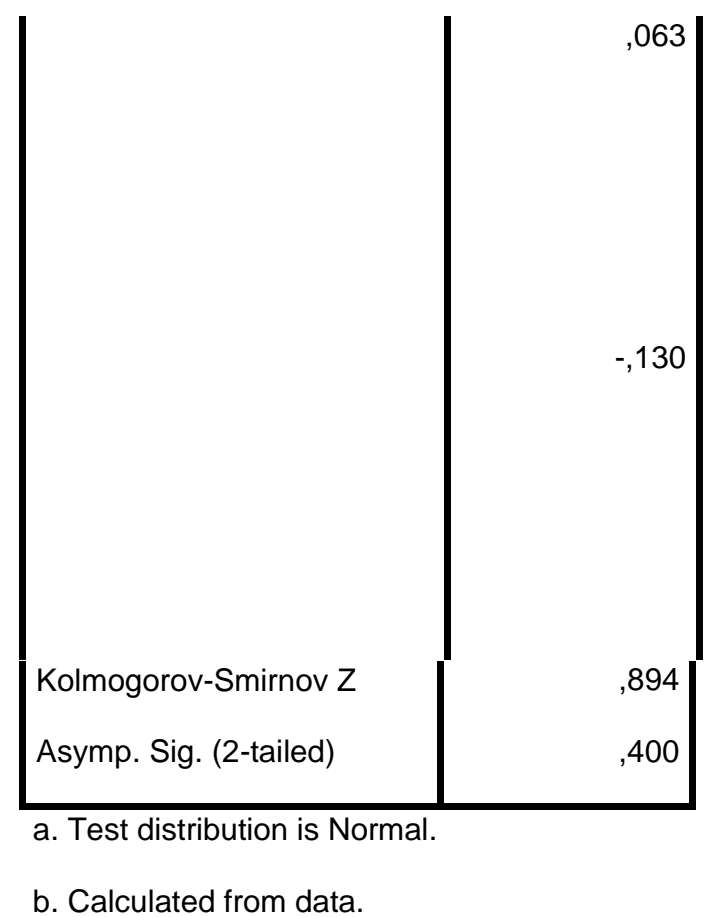

Sumber: Data sekunder diolah dengan SPSS versi 21

Jadi dapat dilihat pada tabel $4.1 \mathrm{di}$ atas menunjukkan besarnya nilai KolmogorovSmirnov Asymp Sig. (2-tailed) pada risidual tersebut sebesar 0,40 >0,05 sehingga dapat disimpulkan bahwa data yang digunakan dalam penelitian ini berdistribusi secara normal.

\section{2) Analisis Grafik Histogram}

Salah satu cara termudah untuk melihat normalitas residual adalah dengan melihat grafik histogram normal probability plot yang membandingkan antara data observasi dengan distribusi yang mendekati distribusi normal.

\section{Gambar 1 \\ Hasil Uji Normal P-P Plot}

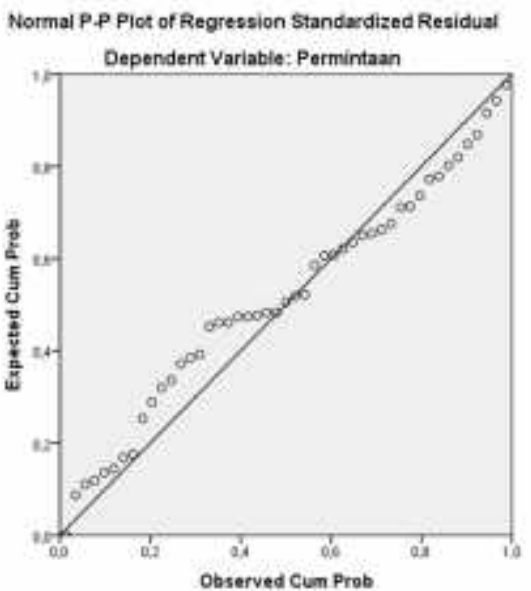

Sumber: Data sekunder diolah dengan SPSS versi 21

Berdasarkan grafik normal probability plot terlihat bahwa data menyebar di sekitar garis diagonal dan mengikuti arah garis diagonal. Kesimpulan yang dapat diambil berdasarkan hipotesis uji normalitas adalah data berdistribusi normal sehingga memenuhi asumsi klasik uji normalitas.

\section{b) Uji Heteroskedastisitas}

Dalam persamaan regresi berganda perlu juga diuji mengenai sama atau tidak varians dari residual dari observasi yang satu dengan observasi yang lain. Jika residualnya mempunyai varians yang sama, disebut terjadi homoskedastisitas, dan jika variansnya tidak sama/ berbeda disebut terjadi heteroskedastisitas. 
Gambar 2

Hasil Uji Heterokedastisitas

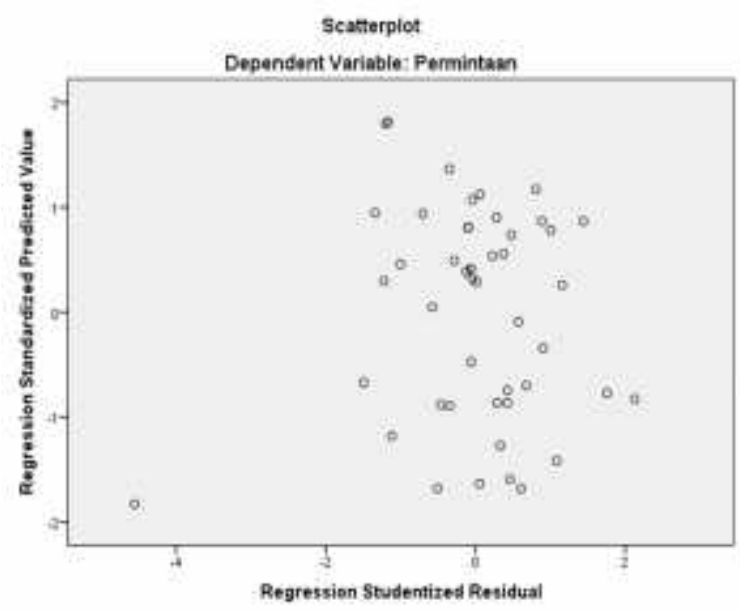

Sumber: Data sekunder diolah dengan SPSS versi 21
Berdasarkan grafik scatterplot diatas terlihat bahwa titik-titik menyebar secara acak serta tersebar baik di atas maupun di bawah angka nol pada sumbu Y. Hal ini dapat disimpulkan bahwa tidak terjadi heteroskedastisitas.

\section{c) Uji Multikolinieritas}

Uji multikolinieritas diperlukan untuk mengetahui ada tidaknya variabel independen yang memiliki kemiripan antar variabel independen dalam suatu model. Kemiripan antar variabel independen akan mengakibatkan korelasi yang sangat kuat.

Tabel 2

Hasil Uji Multikoliniearitas

Coefficients $^{\mathrm{a}}$

\begin{tabular}{|c|c|c|c|c|c|c|c|}
\hline \multirow[t]{2}{*}{ Model } & \multicolumn{2}{|c|}{$\begin{array}{l}\text { Unstandardized } \\
\text { Coefficients }\end{array}$} & \multirow{2}{*}{\begin{tabular}{|c|}
$\begin{array}{c}\text { Standardized } \\
\text { Coefficients }\end{array}$ \\
Beta
\end{tabular}} & \multirow[t]{2}{*}{$\mathrm{t}$} & \multirow[t]{2}{*}{ Sig. } & \multicolumn{2}{|c|}{$\begin{array}{l}\text { Collinearity } \\
\text { Statistics }\end{array}$} \\
\hline & $B$ & Std. Error & & & & $\begin{array}{c}\text { Toleranc } \\
\mathrm{e}\end{array}$ & VIF \\
\hline (Constant) & 15,506 & 66,648 & & ,233 & ,817 & & \\
\hline Imbal_hasil & ,387 & ,373 & 291 & 1,040 & ,305 & ,131 & 7,663 \\
\hline Harga & 18,395 & 11,885 & ,250 & 1,548 & ,129 & ,392 & 2,552 \\
\hline Kurs & $-10,816$ & 2,856 &,- 906 & $-3,787$ & ,000 & ,179 & 5,592 \\
\hline Inflasi &,- 210 & ,155 &,- 203 & $-1,361$ & ,181 & ,459 & 2,179 \\
\hline $\begin{array}{l}\text { Suku_bung } \\
\text { a }\end{array}$ & ,988 & ,408 & ,756 & 2,425 & ,020 & ,105 & 9,498 \\
\hline
\end{tabular}

a. Dependent Variable: Permintaan

Sumber: Data sekunder diolah dengan SPSS versi 21
Berdasarkan hasil uji multikolinearitas menunjukkan nilai VIF imbal hasil sebesar 7,663, nilai VIF harga sebesar 2,552, nilai VIF kurs sebesar 5,592, nilai VIF inflasi 
sebesar 2,179, dan nilai VIF suku bunga deposito sebesar 9,498. Berdasarkan hasil pengujian multikolinieritas menunjukkan bahwa semua variabel independen tersebut memiliki nilai VIF sebesar kurang dari 10 (< 10). Maka semua variabel independen tersebut tidak terjadi multikoliniearitas.

\section{d) Uji Autokorelasi}

Uji autokorelasi bertujuan menguji apakah dalam suatu model regresi linear ada kolerasi antara kesalahan pengganggu pada periode $\mathrm{t}$ dengan kesalahan pada periode $\mathrm{t}-1$ (sebelumnya). Jika terjadi korelasi, maka dinamakan ada problem autokorelasi.

\section{Tabel 1.3}

\section{Uji Autokolerasi}

Model Summary

\begin{tabular}{|l|r|r|r|r|r|}
\hline Model & $\mathrm{R}$ & $\mathrm{R}$ Square & \multicolumn{1}{|c|}{$\begin{array}{c}\text { Adjusted } \mathrm{R} \\
\text { Square }\end{array}$} & $\begin{array}{c}\text { Std. Error of the } \\
\text { Estimate }\end{array}$ & Durbin-Watson \\
\hline 1 &, $762^{\mathrm{a}}$ &, 580 &, 529 & 1,13639 & 2,144 \\
\hline
\end{tabular}

a. Predictors: (Constant), Suku_bunga, Harga, Inflasi, Kurs, Imbal_hasil

b. Dependent Variable: Permintaan

Sumber: Data sekunder diolah dengan SPSS versi 21

Dari tabel di atas didapat nilai durbinwatson sebesar 2,144 dan dilihat dari tabel durbin-watson didapat nilai du sebesar 1,7736 dan nilai dl sebesar 1,3073, dengan jumlah $n$ sebanyak 47 dan jumlah variabel bebas sebanyak 5. Sehingga didapatkan hasil ( $\mathrm{du}<2,144<4-\mathrm{du}$ ) atau 1,7736< $2,144<4-1,7736=2,2264$ karena nilai D-W berada diantara nilai du dan $4-d u$, maka dapat disimpulkan bahwa antara variabel bebas tidak terdapat autokorelasi.

\section{Analisis Regresi Linier Berganda}

Regresi linier berganda adalah regresi di mana variabel terikat (Y) dihubungkan/dijelaskan lebih dari satu variabel, mungkin dua, tiga, dan seterusnya varibel bebas $\left(\mathrm{X}_{1}, \mathrm{X}_{2}, \mathrm{X}_{3}, \ldots, \mathrm{X}_{\mathrm{n}}\right)$ namun masih menunjukkan diagram hubungan yang linier. Penambahan variabel bebas ini diharapkan dapat lebih menjelaskan karakteristik hubungan yang ada, walaupun masih saja ada variabel yang terabaikan. ${ }^{13}$

Penelitian ini, yang menjadi variabel terikat (dependen) adalah permintaan sukuk

\footnotetext{
${ }^{13}$ Hasan, M. Iqbal. Pokok - Pokok Materi Statistik 1. (Jakarta: PT. Bumi Aksara, 2008). h. 125
} 
negara ritel, sedangkan variabel bebas $\mathrm{X} 1=$ Imbal hasil

(independen) adalah imbal hasil sukuk ritel, $\mathrm{X} 2=$ Harga sukuk ritel

kurs, harga sukuk ritel, inflasi, dan suku X3 = Kurs dolar AS

bunga (BI Rate). $\quad$ X4 = Inflasi

Persamaan analisis regresi linier X5 `= Suku bunga (BI- Rate)

berganda dalam penelitian ini dirumuskan $\mathrm{e}=$ Error term (kesalahan sebagai berikut:

$$
\mathrm{Y}=\mathrm{a}+\mathrm{b} \mathrm{X}_{1}+\mathrm{c} \mathrm{X}_{2}+\ldots+\mathrm{k} \mathrm{X}_{\mathrm{k}}+\mathrm{e}
$$

pengganggu)

\section{Uji Hipotesis}

\section{a. Uji t (Parsial)}

Keterangan :

$\mathrm{Y}=$ Permintaan sukuk negara ritel

$\alpha \quad=$ Konstanta

$\mathrm{a}, \mathrm{b}, \mathrm{c}, \ldots \mathrm{k}=$ Koefisien regresi

Uji hipotesis $t$ pada dasarnya menunjukkan seberapa jauh pengaaruhnya satu variabel independen secara individual dalam menerangkan variasi variabel dependen.

\section{Tabel 1.4}

\section{Hasil Uji t}

Coefficients $^{a}$

\begin{tabular}{|r|r|r|r|r|r|}
\hline Model & \multicolumn{2}{|c|}{ Unstandardized Coefficients } & \multicolumn{1}{c|}{$\begin{array}{c}\text { Standardized } \\
\text { Coefficients }\end{array}$} & Sig. \\
\cline { 2 - 5 } & B & Std. Error & Beta & \\
\hline (Constant) & 15,506 & 66,648 & &, 233 &, 817 \\
Imbal_hasil &, 387 &, 373 &, 291 & 1,040 &, 305 \\
Harga & 18,395 & 11,885 &, 250 & 1,548 &, 129 \\
Kurs & $-10,816$ & 2,856 &,- 906 & $-3,787$ &, 000 \\
Inflasi &,- 210 &, 155 &,- 203 & $-1,361$ &, 181 \\
Suku_bunga &, 988 &, 408 &, 756 & 2,425 &, 020 \\
\hline
\end{tabular}

a. Dependent Variable: Permintaan

Sumber: Data sekunder diolah dengan SPSS 
a. Pengujian Hipotesis Pertama

Berdasarkan hasil pengolahan data diperoleh nilai probabilitas signifikansi imbal hasil sukuk ritel sebesar $0,305>0,05$. Pengembalian keputusan yang dapat diambil menyatakan bahwa $\mathrm{H}_{0}$ diterima dan $\mathrm{H}_{\mathrm{a}}$ ditolak di karenakan nilai probabilitas (signifikansi) dari imbal hasil sukuk ritel lebih besar dari 5\% $(0,05)$. Sehingga imbal hasil sukuk ritel tidak berpengaruh signifikan terhadap tingkat permintaan sukuk negara ritel.

\section{b. Pengujian Hipotesis Kedua}

Berdasarkan hasil pengujian diketahui bahwa nilai probabilitas signifikansi harga sukuk sebesar $0,129>0,05$. Pengambilan keputusan yang dapat diambil menyatakan bahwa $\mathrm{H}_{0}$ diterima dan $\mathrm{H}_{\mathrm{a}}$ ditolak dikarenakan nilai probabilitas (signifikansi) dari harga lebih besar dari 5\% $(0,05)$. Sehingga harga tidak berpengaruh signifikan terhadap tingkat permintaan sukuk negara ritel.

\section{c. Pengujian Hipotesis Ketiga}

Berdasarkan hasil pengujian diketahui bahwa nilai probabilitas signifikansi tingkat inflasi sebesar $0,000<0,05 . \quad$ Pengambilan keputusan yang dapat diambil menyatakan bahwa $\mathrm{H}_{0}$ ditolak dan $\mathrm{H}_{\mathrm{a}}$ diterima dikarenakan nilai probabilitas (signifikansi) dari harga lebih kecil dari 5\% $(0,05)$. Sehingga kurs berpengaruh negatif dan signifikan terhadap tingkat permintaan sukuk negara ritel.

\section{d. Pengujian Hipotesis Keempat}

Berdasarkan hasil pengujian diketahui bahwa nilai probabilitas signifikansi inflasi sebesar $0,181>0,05$. Pengambilan keputusan yang dapat diambil menyatakan bahwa $\mathrm{H}_{0}$ diterima dan $\mathrm{H}_{\mathrm{a}}$ ditolak dikarenakan nilai probabilitas (signifikansi) dari harga lebih besar dari 5\% $(0,05)$. Sehingga harga tidak berpengaruh signifikan terhadap tingkat permintaan sukuk negara ritel.

\section{e. Pengujian Hipotesis Kelima}

Berdasarkan hasil pengujian diketahui bahwa nilai probabilitas signifikansi tingkat inflasi sebesar $0,020<0,05$. Pengambilan keputusan yang dapat diambil menyatakan bahwa $\mathrm{H}_{0}$ ditolak dan $\mathrm{H}_{\mathrm{a}}$ diterima dikarenakan nilai probabilitas (signifikansi) dari harga lebih kecil dari 5\% $(0,05)$. Sehingga suku bunga deposito berpengaruh positif dan signifikan terhadap tingkat permintaan sukuk negara ritel.

\section{b. Uji F (uji simultan)}

Uji $\mathrm{F}$ pada dasarnya menunjukkan apakah semua variabel bebas yang dimaasukkan dalam model mempunyai pengaruh secara bersama - sama terhadap variabel terikat. 

Tabel 1.5

Hasil Uji F (Simultan)

ANOVA $^{\mathrm{a}}$

\begin{tabular}{|c|c|c|c|c|}
\hline Model & Sum of Squares & $\mathrm{df}$ & Mean Square & $\mathrm{F}$ \\
\hline $\begin{array}{l}\text { Regression } \\
\text { Residual } \\
\text { Total }\end{array}$ & $\begin{array}{r}73,209 \\
\\
52,947 \\
126,156\end{array}$ & $\begin{array}{r}5 \\
\\
41 \\
46\end{array}$ & 14,642 & 11,338 \\
\hline
\end{tabular}

a. Dependent Variable: Permintaan

b. Predictors: (Constant), Suku_bunga,

Harga, Inflasi, Kurs, Imbal_hasil

Sumber: Data sekunder diolah dengan SPSS versi 21

Dari hasil uji $\mathrm{F}$ diketahui bahwa Nilai probabilitas lebih kecil dari batas nilai signifikan $\alpha=0,05 \%$ yaitu $0,000<0,05$, maka pada model regresi penelitian ini dapat ditarik kesimpulan bahwa imbal hasil suku ritel, harga suku ritel, kurs, inflasi, dan suku bunga deposito secara simultan berpengaruh terhadap permintaan sukuk negara ritel.

\section{c. Koefisien Determinasi $\left(\mathbf{R}^{2}\right)$}

Koefisisen determinasi $\left(\mathrm{R}^{2}\right)$ pada intinya mengukur seberapa jauh kemampuan model dalam menerangkan variasi variabel terikat. Nilai koefisien determinasi adalah di antara nol dan satu. Nilai $\mathrm{R}^{2}$ yang kecil berarti kemampuan variabel - variabel independen dalam menjelaskan variasi variabel dependen amat terbatas.

Tabel 1.6

\section{Hasil Uji Determinasi $\left(\mathbf{R}^{2}\right)$}

Model Summary

\begin{tabular}{|l|l|r|r|c|}
\hline Model & $\mathrm{R}$ & $\mathrm{R}$ Square & $\begin{array}{c}\text { Adjuted } \mathrm{R} \\
\text { Square }\end{array}$ & $\begin{array}{c}\text { Std. } \\
\text { Error of } \\
\text { the } \\
\text { Estimat } \\
\mathrm{e}\end{array}$ \\
\hline 1 &, $762^{\mathrm{a}}$ &, 580 &, 529 & 1,13639 \\
\hline
\end{tabular}

a. Predictors: (Constant), Suku_bunga, Harga, Inflasi, Kurs, Imbal_hasil

Sumber: Data sekunder diolah dengan PSS versi 21 
Berdasarkan hasil perhitungan uji imbal hasil yang diberikan lebih besar dari determinasi pada tabel di atas, tampak bahwa pada imbal hasil sukuk negara ritel itu besarnya koefisien determinasi atau $R$ sendiri. Berdasarkan hasil analisis regresi Square sbesar 0,580. Hal ini menunjukkan imbal hasil sukuk negara ritel tidak bahwa 58\% variabel dependen permintaan berpengaruh signifikan terhadap tingkat sukuk ritel dipengaruhi oleh variabel permintaan sukuk negara ritel. Hasil independen imbal hasil sukuk negara ritel, penelitian ini sejalan dengan penelitian harga sukuk negara ritel, kurs, tingkat inflasi, Thompson dan Vaz serta Nurfauziah dan dan tingkat suku bunga deposito. Sedangkan Setyarini yang menemukan hasil bahwa sisanya $42 \%(100 \%-58 \%)$ dipengaruhi oleh tingkat suku bunga obligasi tidak variabel lain yang tidak dimasukkan dalam berpengaruh signifikan terhadap yield model persamaan regresi ini.

\section{ANALISIS}

1. Pengaruh imbal hasil sukuk negara ritel terhadap tingkat permintaan sukuk negara ritel.

Pembayaran imbalan ('ujrah) dalam perjanjian sewa pada sukuk negara ritel adalah bersifat tetap (fixed) yang dilakukan secara periodik sampai jatuh tempo (maturity date). Sehingga dapat dengan mudah diprediksi berapa yang akan didapatkan. Sedangkan investasi syariah yang lainnya misalnya seperti deposito mudharabah dan sukuk mudharabah, memberikan bagi hasil yang fluktuatif atau tidak tetap. Semakin tinggi penempatan dana oleh nasabah ke produk deposito akan memberikan imbal hasil yang semakin tinggi pula. Dengan demikian investor akan mengalihkan dananya dari sukuk ke investasi lain apabila obligasi. Hasil penelitian tersebut berbeda dengan yang dilakukan oleh Kadir yang menunjukkan hasil bahwa terdapat pengaruh positif dan signifikan antara tingkat suku bunga terhadap tingkat imbal hasil obligasi. Selain faktor imbal hasil tetap faktor lain yang menyebabkan imbal hasil tidak berpengaruh terhadap permintaan sukuk ritel yaitu disebabkan karena adanya faktor makro ekonomi, yaitu hal yang mengkhawatirkan investor tidak lain adalah sentimen dari dalam negeri sendiri, terutama menyangkut data perlambatan ekonomi Indonesia pada kuartal I 2015 di angka 4,7\% dan kuartal II di level 4,67\% rupiah pun ikut melemah.

2. Pengaruh harga sukuk negara ritel terhadap tingkat permintaan sukuk negara ritel.

Harga sukuk negara ritel merupakan harga jual dimana harganya dihitung pada setiap 
akhir transaksi setiap hari aktif transaksi pasar sekunder dengan perhitungan indeks. Harga sukuk negara ritel berubah setiap harinya tergantung kondisi pasar dan kondisi makro ekonomi saat itu pula. Berdasarkan hasil analisis regresi harga sukuk negara ritel tidak berpengaruh signifikan terhadap tingkat permintaan sukuk negara ritel. Hasil penelitian ini sejalan dengan penelitian Ulinuha Notavia yang menyatakan bahwa harga sukuk negara ritel tidak dapat mempengaruhi besar kecilnya tingkat permintaan sukuk negara ritel SR 004. Harga sukuk negara ritel merupakan harga jual dari sukuk ritel di pasar modal yang dihitung berdasarkan indeks. Hasil penelitian ini tidak sejalan dengan penelitian Muhammad Agus Khairul Wafa' yang menyatakan bahwa harga sukuk negara ritel dapat mempengaruhi besar kecilnya tingkat permintaan sukuk ritel SR 001, dalam penelitian ini arahnya negatif yang berarti bahwa apabila harga sukuk negara ritel mengalami penurunan, maka tingkat permintaan sukuk ritel mengalami kenaikan dan sebaliknya.

Berdasarkan kedua hasil analisis diatas dapat disimpulkan bahwa pengaruh tidaknya harga sukuk ritel terhadap permintaan sukuk ritel berbeda pada setiap periode penelitiannya dan juga pada jenis seri berapa yang di teliti. Tetapi berdasarkan hasil penelitian yang penulis lakukan dari periode tahun 2012-2015 sukuk ritel SR 004-007 (lebih dari satu seri). Mendapatkan hasil bahwa harga sukuk negara ritel tidak berpengaruh terhadap tingkat permintaan sukuk negara ritel.

\section{Pengaruh kurs terhadap tingkat permintaan sukuk negara ritel.}

Permintaan dolar AS juga bisa tinggi karena investor ramai-ramai mengubah portofolionya dari saham ke valas, inilah yang membuat rupiah melemah di saat krisis finansial global. Tingginya mata uang asing akan mendorong investor untuk berinvestasi di pasar uang, tentunya dengan alasan tingkat keuntungan yang diharapkan. Hal ini memberikan pengaruh negatif terhadap pasar modal yang akan mengakibatkan harga saham akan mengalami penurunan.

Berdasarkan hasil analisis regresi nilai tukar (kurs dolar AS) berpengaruh signifikan terhadap tingkat permintaan sukuk negara ritel. Hasil penelitian ini sejalan dengan penelitian yang dilakukan oleh Wiyani, Wahyu dan Andi Wijayanto yang meneliti tentang pengaruh nilai tukar rupiah tingkat suku bunga deposito dan volume perdagangan saham terhadap harga saham. Maka dari penjelasan dan pemaparan di atas untuk peneliti menyimpulkan bahwa kurs rupiah mempunyai pengaruh terhadap 
investasi pada pasar modal salah satunya adalah sukuk negara ritel.

Di luar itu, hal yang mengkhawatirkan investor tidak lain adalah sentimen dari dalam negeri sendiri, terutama menyangkut data perlambatan ekonomi Indonesia pada kuartal I 2015 di angka 4,7\% dan kuartal II di level 4,67\%. Rupiah pun ikut melemah. Walaupun demikian, investor diminta tidak panik sebab tidak ada badai yang tidak berlalu. Berdasarkan berita di atas dapat disimpulkan bahwa investor panik dengan terjadinya perlambatan ekonomi yang mengakibatkan rupiah melemah sehingga kurs dolar AS meningkat. Sehingga memilih untuk sementara tidak berinvestasi pada sukuk negara ritel pada periode tersebut.

4. Pengaruh tingkat inflasi terhadap tingkat permintaan sukuk negara ritel.

Turunnya nilai mata uang akan melibatkan pembeli, karena ia akan kehilangan uang sebanyak yang dibayarkan untuk membeli obligasi. Kenaikan inflasi akan menggerus pendapatan riil nilai kupon ataupun sewa kupon yang dimiliki oleh investor.

Berdasarkan hasil analisis regresi inflasi tidak berpengaruh signifikan terhadap tingkat permintaan sukuk negara ritel. Penelitian ini sejalan dengan penilitian yang dilakukan oleh Agus Zainul Arifin yang mengatakan bahwa besarnya tingkat inflasi menjadi sangat penting bagi investor dalam menentukan nilai riil pendapatan. Bagi investor, ia akan lebih peduli terhadap real rate return dari dananya, karena menunjukkan purchasing power (daya beli) dari berbagai perolehan bunga (bagi hasil). Semakin tinggi inflasi maka semain rendah nilai riil imbal hasil, hal ini disebabkan karena sukuk memberikan imbalan yang tetap sehingga menurunkan permintaan. Namun bertolak belakang dengan hasil penelitian Hulwati yang menyatakan bahwa tingkat inflasi berpengaruh terhadap tingkat obligasi.

Penelitian ini juga tidak sesuai dengan teori yang menyatakan bahwa tingkat inflasi berpengaruh negatif terhadap permintaan sukuk. Namun, hal ini dikarenakan tingkat inflasi dalam periode penelitian masih dalam klarifikasi inflasi ringan (2011; 2,7\%, 2012; $4,21 \%$, dan $2013 ; 8,13 \%<10 \%$ ) atau masih dalam satu digit. Sehingga penurunan nilai imbal hasil yang akan diterima investor tidak begitu menggerus nilai riil pendapatan dan masih dalam ekspektasi investor dalam menempatkan dananya.

5. Pengaruh suku bunga deposito terhadap tingkat permintaan sukuk negara ritel. 
Deposit (time deposito) adalah salah satu tempat melakukan investasi oleh nasabah dalam bentuk surat-surat berharga. Kepada nasabah yang menginvestasikan dana dalam simpanan (deposito) maka akan diberikan imbalan bunga atas depositonya.

Berdasarkan hasil analisis regresi tingkat suku bunga deposito berpengaruh signifikan terhadap tingkat permintaan sukuk negara ritel. Hasil penelitian ini sejalan dengan hasil penelitian yang dilakukan oleh Idris dan Hasdi Aimon yang menyatakan suku bunga SBI berpengaruh terhadap tingkat permintaan obligasi pemerintah dan arahnya positif.

Apabila suku bunga SBI meningkat maka permintaan obligasi pemerintah juga akan meningkat, begitu juga sebaliknya. Pada harga yang rendah jumlah permintaan obligasi akan lebih tinggi. Di samping itu tingkat bunga yang tinggi juga akan menyebabkan return yang diisyaratkan investor dari suatu investasi akan meningkat, hal ini akan meningkatkan permintaan terhadap obligasi. Hasil penelitian ini bertolak belakang dengan penelitian yang dilakukan oleh Muhammad Agus Khairul Wafa', yang menyatakan bahwa tingkat bagi hasil deposito mudharabah berpengaruh terhadap permintaan sukuk ritel SR 001.

Dalam memilih deposito, investor harus memprediksi terlebih dahulu berapa besar manfaat yang akan diberikan oleh perbankan. Hal tersebut dikarenakan suku bunga (ekuivalen rate) ditentukan di akhir periode bukan di awal. Sehingga sulit untuk menetapkan berapa manfaat yang akan didapatkan oleh investor. Sedangkan sukuk ritel memberikan sewa yang tetap (fixed rate), tidak akan berubah walau terjadi kenaikan suku bunga acuan BI rate / suku bunga SBI. Suku bunga deposito memiliki nilai tertinggi hanya sebesar $8,63 \%$ yang terjadi pada bulan Mei 2015, nilai tertinggi imbal hasil sukuk negara ritel pada periode tersebut sebesar $8,75 \%$ SR 006 pada bulan maret 2014 sampai maret 2016, lebih besar dari pada suku bunga yang diberikan bank umum. Perbedaan yang tipis antara imbal hasil sukuk ritel dengan suku bunga deposito menyebabkan pengaruh positif terhadap permintaan sukuk negara ritel.

\section{DAFTAR PUSTAKA}

Arifin, Agus Zainul. "Inflasi, Kurva Yield, dan Durasi: Kajian Teori dalam Perspektif Praktis." Manajemen dan Bisnis Sriwidjaya. Vol. 5, No. 10. Desember 2007.

Bank Indonesia. "Informasi Kurs." http://www.bi.go.id/id/moneter/inform asi-kurs/transaksi-bi/Default.aspx (diakses 27 April 2016)

Ghozali, Imam. Aplikasi Analisis Multivariate dengan SPSS. Semarang: Badan Penerbit Universitas Diponegoro, edisi 3, 2005. 
Hasan, M. Iqbal. Pokok - Pokok Materi Statistik 1. Jakarta: PT. Bumi Aksara, 2008 .

HR, Muhamad Nafik. Bursa Efek dan Investasi Syariah. Jakarta: PT Serambi Ilmu Semesta 2009.

Idris dan Hasdi Aimon. "Suku Bunga Bank Indonesia (SBI), Harga Surat Utang Negara dan Penawaran Obligasi Pemerintah terhadap Permintaan Obligasi Pemerintah di Indonesia." Kajian Ekonomi. Vol. 1, No. 2, Januari 2013.

Jusmaliani. Dkk. Bisnis Berbasis Syariah. Jakarta: Bumi Aksara,2008.

Kementrian Keuangan Republik Indonesia. Laporan Kinerja. Jakarta: Kementrian Keuangan, 2015.

Al Arif, M.Nur Rianto. Teori Makroekonomi Islam; Konsep, Teori, dan Analisis. Bandung: Alfabeta, 2010.

Mankiw, N. Gregory. Dkk. Pengantar Ekonomi Makro. Jakarta: Salemba Empat, 2013.

Martin. "Pengaruh Suku Bunga Terhadap Nilai Tukar Mata Uang." http://seputarforex.com/artikel/forex/li hat.php?id=128564\&title=pengaruh_su ku_bunga_terhadap_nilai_tukar_mata_ uang (diakses 21 April 2016)

Pratiwi, Fuji. "Inflasi Stabil Pengaruhi Suku Bunga", Republika (Ekonomi), Jakarta, 23 Maret, 2016, 2
Pratiwi, Fuji, "Penerbitan Sukuk Dolar Dinilai Positif," Republika (Syariah), Jakarta, 19 Desember, 2015.

Pratiwi, Fuji. "Timur Tengah Tutup Defisit dengan Sukuk", Republika (Ekonomi), Jakarta, 26 Januari, 2016, 2

S, Burhanuddin. Hukum Surat Berharga Syariah Negara dan Pengaturannya. Jakarta : Rajawali Pers 2011.

Sujarweni, V. Wiratna. Metodologi Penelitian Bisnis dan Ekonomi. Yogyakarta: Pustaka Baru Press, 2015.

Sukirno, Sadono. Makro Ekonomi; Teori Pengatar. Jakarta: Rajawali Pers, 2013.

Swandayani, Desi Marlin \& Rohmawati Kusumaningtias, " Pengaruh Inflasi, Suku Bunga, Nilai Tukar Valas dan Jumlah Uang Beredar terhadap Profitabilitas pada Perbankan Syariah di Indonesia Periode 2005-2009," Akrual 3, 2012.

Wafa', Muhammad Agus Khairul. "Analisis Faktor-Faktor Yang Mempengarui Permintaan Sukuk Ritel 001." La Riba. Vol. 5, No. 2. 2010.

Widoatmodjo, Sawidji. Cara Sehat Investasi di Pasar Modal; Pengantar Menjadi Investor Profesional. Jakarta: Kompas Gramedia,

2012 